\title{
LEADERSHIP STYLE, CRISIS RESPONSE AND BLAME MANAGEMENT: THE CASE OF HURRICANE KATRINA
}

\author{
ARJEN BOIN, PAUL 'T HART, ALLAN McCONNELL AND THOMAS PRESTON
}

Crisis management research has largely ignored one of the most pressing challenges political leaders are confronted with in the wake of a large-scale extreme event: how to cope with what is commonly called the blame game. In this article, we provide a heuristic to help understand political leader responses to blame in the aftermath of crises, emphasizing the crucial role of their leadership style on the political management of Inquiries. After integrating theoretical and empirical findings on crisis management and political leadership styles, we illustrate our heuristic by applying it to the Bush administration's response to Hurrican Katrina in 2005. We conclude by offering suggestions for further research on the underdeveloped subject of the blame management challenges faced by political leaders in the wake of acute crisis episodes.

\section{POLITICAL LEADERSHIP IN THE AFTERMATH OF CRISIS}

The management of urgent threats to core societal values, critical infrastructures and the safety of citizens is an elementary function of government. It requires political and administrative leadership (Boin et al. 2005). Effective crisis leadership entails recognizing emerging threats, initiating efforts to mitigate them and deal with their consequences, and, once an acute crisis period has passed, re-establishing a sense of normalcy. These are no easy tasks in a time of new threats and increasingly vulnerable societies.

Much attention in both research and practice has traditionally focused on the acute response phase: the critical decisions that must be made during a crisis and the perennial difficulties in communicating these decisions to a frightened public (see, for example, Flin 1996; Rosenthal et al. 1989; Ulmer et al. 2007). In recent disasters, however, it was the 'crisis after the crisis' that held societies spellbound. In Western societies, the post-crisis phase is increasingly marked by intense politicization ('t Hart 1993; Olson 1998; Rosenthal 1998; Boin et al. 2008). While the crisis is still unfolding, the drama of accountability and blaming begins. Surprisingly, however, little has been written about the wider political leadership challenges generated by the 'crisis after the crisis'. These challenges focus on the management of accountability and the avoidance of blame that tends to be apportioned in the wake of extraordinary, disturbing and destabilizing events. When crises occur, something or somebody must be blamed - for causing the crisis, failing to prevent it, or inadequately responding to it (Bovens and 't Hart 1996; Hood 2002). Governments and their leaders are often key targets for these blaming impulses.

Some analysts have explored the causes and drivers of blame games and blame management (Weaver 1986; Ellis 1994; Hood 2002; Hearit 2006; Hood et al. 2009). Others have detailed how crisis-induced political blame games generally unfold (McGraw 1990, 1991; Brändström and Kuipers 2003). Our particular interest is whether the leadership styles of political leaders can help explain the dynamics and outcome of these crisisinduced blame games (Parker and Dekker 2008; Hood et al. 2009).

Arjen Boin is affiliated with the Utrecht School of Governance and the Public Administration Institute, Louisiana State University. Paul 't Hart is in the Research School of Social Sciences, Australian National University. Allan McConnell is a Professor of Politics at the University of Strathclyde and the University of Sydney. Thomas Preston is in the Department of Political Science, Washington State University.

Public Administration Vol. 88, No. 3, 2010 (706-723)

(C) 2010 Blackwell Publishing Ltd, 9600 Garsington Road, Oxford OX4 2DQ, UK and 350 Main Street, Malden,

MA 02148, USA. 
Hurricane Katrina is a prime case for studying political leadership and the post-crisis blame game. Katrina hit the US Gulf Coast in the late summer of 2005, overwhelming local, state and national governments. The preparedness and performance of politicians, administrators and public institutions at all levels was criticized, but President George $\mathrm{W}$. Bush received most of the blame for the slow and ineffective response. His attempts to deflect blame (from the 'unforseeability' of the levees being breached through to the failings of state and city officials) only made things worse, creating the impression of an out-of-touch and insensitive president. The aim of this article, therefore, is to explain why George W. Bush adopted and continued to adhere to a blame management strategy that proved ineffective and counterproductive.

We begin by delineating the general challenges that political leaders face in the postcrisis phase. We then explore in detail the case of President George W. Bush and the aftermath of Hurricane Katrina. This is a particularly interesting case because it features George W. Bush, a previously successful crisis leader in the immediate wake of the 9/11 attacks, in what is widely considered to be one of the worst failures of crisis leadership in recent US history (the response to Hurrican Katrina). In addition, this disaster and its aftermath have been extremely well documented, which is helpful for an analysis of leadership behaviour. While the choice of one case prohibits us from generalizing our findings, we nevertheless conclude by suggesting that our framework, which emphasizes the interplay between crisis-induced leadership challenges and leadership style, has the potential to help explain the dynamics and outcome of post-crisis blaming processes for other cases.

\section{THE POLITICS OF CRISES: INQUIRY, ACCOUNTABILITY AND BLAME GAMES}

One of the chief claims legitimizing incumbent leaders and governments is that they protect public order, health and safety. The onset of crisis breaches this claim. We define crises in terms of legitimacy shortfalls as a 'breakdown of familiar symbolic frameworks legitimating the pre-existing socio-political order' ('t Hart 1993, p. 39). In the wake of a crisis, the public, the media and political opponents tend to examine the crisis management performance of incumbents. They want to know what went wrong, what was (not) done to prevent and contain the crisis, and who should be held responsible.

A crisis thus opens up opportunities for challenging and changing the status quo. Depending on the duration of their incumbency and their prior political commitments, incumbent leaders may push for reform, whereas opposition forces may defend the status quo or, as appears to occur more frequently, the opposite. Whether change happens, and how it plays out, depends to a significant degree on the interactions between incumbents and critics as they battle each other during the post-crisis phase (Boin et al. 2008). They battle to get their definition of the crisis accepted as the official account of events. They typically argue about the significance of the crisis (how bad was it really?); they also contest whether the crisis should be seen as an incident or an indicator of structural failure. The winning contest brings spoils to its sponsor, determining who or what should be blamed. One important venue for these battles is the Official Inquiry, something which, today, appears a near-inevitable by-product of crises (Kitts 2006; Prasser 2006; Drennan and McConnell 2007; Parker and Dekker 2008). The media provide another, complementary, venue for 'frame warriors' who seek to impose their definition of the crisis through media representatives. 
Two factors are important in determining the outcome of post-crisis blame games (Boin et al. 2009): (1) the extent to which blame for the mismanagement of a crisis is attributed to leaders and governments (by Inquiries, the press, legislators); (2) the political astuteness of the blame management behaviour of leaders during and in response to crisis Inquiries. In this article, we study the latter and explore how it relates to the former.

The political astuteness of crisis leaders is tested during a number of recurrent blame management challenges, which consistently and persistently manifest themselves in the wake of crises and disasters. Leaders have to formulate a strategy with regard to: (1) the interaction with Inquiry bodies and media representatives; (2) the response to findings and recommendations produced by Inquiry bodies and media representatives; and (3) the management of the political impact of 'public verdicts' whether produced by Inquiries or media investigations.

In formulating their strategy, leaders have to negotiate a deeply entrenched tension: they must consolidate, restore and show faith in the security and validity of pre-existing social, institutional and political arrangements. However, they also face pressures to criticize and reform these same arrangements (Boin and 't Hart 2003). They must navigate a difficult pathway between an open, reflective, responsibility-accepting stance that encourages policy-oriented learning but may leave them politically vulnerable, and a defensive, responsibility-denying stance that may deflect blame at the price of undermining learning and eroding a leader's long-term legitimacy.

These challenges encompass a mixture of agency, policy and presentational strategies of blame management commonly distinguished in the literature (see Weaver 1986; McGraw 1990, 1991; Hood 2002). Leaders vary in their responses, and responses vary in their blame management effectiveness (Brändström et al. 2008; Hood et al. 2009). Some researchers suggest that the overall pattern is one of 'staged retreat' - moving from denying that there is a problem to admitting there is a problem but denying responsibility for it, to admitting both problem and responsibility. The evidence, however, is mixed (Hearit 2006; Hood et al. 2009; see also McGraw 1990, 1991). Before we explore how existing theories of leadership style can be adapted to explain the choice of strategy, we will first outline the political challenges that emerge after a crisis.

\section{Challenge 1: Facing inquiries - stonewalling versus co-operation}

Scrutiny typically begins before the crisis is over. Leaders will be expected to co-operate in providing access to information and government witnesses. They may be reluctant to do so and they may succumb to the temptation to shirk, avert, 'spin', or engage in outright confrontation. Leaders can 'stonewall' fact-finding efforts by keeping tabs on files, people and other sources of information. They can also pretend to co-operate and flood their inquisitors with truck loads of mostly tangential records. They can try and put a positive spin on all the information they provide to investigators and reporters. Whether these tactics will be effective at a time when the full force of journalistic, political and sometimes judicial inquiry into executive actions is unleashed, is, of course, a different question.

Political leaders usually realize that it is futile to oppose Public Inquiries into large-scale crises and disasters. But there is plenty they can do to constrain Inquiry mandates. Frontloading tactics include restricting the terms of reference of the investigation, hand-picking 'friendly' or malleable chairpersons, and limiting the time and resources made available (Elliot and McGuiness 2002; Toft and Reynolds 2005; Prasser 2006; Resodihardjo 2006; Shenon 2008). Such tactics may rebound. Some Inquiries have been tainted with accusations about government manipulation: the Warren Commission and the assassination of 
JFK; the FBI/NSTSB investigation into the fall of TWA flight 800 in 1996; the RAF Inquiry into the 1994 crash in Scotland of a Chinook helicopter carrying secret service personnel - these are but a few examples. Being seen to be compromising the search for 'the truth' may do considerable damage to public support for incumbent leaders and governments.

Leaders can also adopt a more co-operative stance. They can endorse the creation of a genuinely independent and/or bipartisan legislative inquiry. Such an inquiry is typically chaired by highly reputable, independently minded officials, it has wide terms of reference and is well resourced. This may work well for all involved. After all, a politically dangerous crisis is truly defused when incumbent leaders have been cleared or exonerated by an Official Inquiry that is widely perceived as thorough and independent. UK Prime Minister Tony Blair found himself in this position after the Butler Inquiry into the accuracy of intelligence rescued him from further political damage over the Iraq conflict.

To some extent, incumbents and investigators have overlapping interests: an Inquiry needs 'inside' material and political leaders want to be seen as co-operative. A typical solution, then, is to negotiate terms of access and co-operation, for example, whether and how leaders can be interviewed, which documents and officials will be made available, and whether the conclusions of the Inquiry will be first discussed with the incumbent leaders (something which provides them with time to prepare their personal 'spin' following publication). The strategy can, however, backfire. A fully independent and thorough inquiry that exposes and condemns government failures puts leaders' careers on the line. It may even topple governments, as happened when the Dutch cabinet resigned in 2002 after the publication of the Official Inquiry into the role of Dutch peacekeepers in the 1995 Srebrenica massacre.

\section{Challenge 2: Dealing with public criticism - denying versus acknowledging fault}

A major challenge for leaders is how to react to negative yet authoritative appraisals of their crisis management performance. Leaders may attempt to conserve their legitimacy either by accepting responsibility or by denying it and blaming force majeure or other actors for damages, glitches and errors. The latter appears to happen more often than the former (Hood 2002; Brändström and Kuipers 2003). Denial has become much easier for politicians who have their key agencies operate at arm's length from their government (Weaver 1986; Flinders and Smith 1999; Hood 2002), inhabit highly decentralized government systems, or govern fragmented policy networks systems. The US federal system, for example, is built on the concept of democratic strength through the separation and sharing of powers at federal and state levels. One by-product of such fragmentation is the creation of legal and political 'space' for the excuse of 'many hands' and widespread finger pointing to other players in the system of governance (Thompson 1980; Bovens 1998).

Offering others up for blame holds out the hope of deflecting it away from oneself. In his landmark study of American presidential use of subordinates as 'lightning rods', Ellis (1994, p. 8) notes that the term suggests 'not merely the attraction of criticism but the deflection of criticism away from someone or something'. For the strategy to be successful, it requires presidents to 'keep their intentions ambiguous', allowing opponents to believe that if the president had paid closer attention, or been more involved, that he would have behaved differently (and better) than the subordinate (Ellis 1994, p. 22). Of course, this tactic only works when such 'ambiguity of intentions' doesn't come across as being 'out of touch.' Indeed, as Ellis (1994, p. 169) observes, 'the success of a lightning rod strategy is contingent on the degree to which people expect a president to be in command of a policy 
area. The greater the expectation of presidential involvement and control, the less likely a president will be able to deflect blame for administration actions onto subordinates'.

Blaming others for crisis-related failures can be politically expedient, but it may also lead to accusations of a failure to accept responsibility. The Swedish Prime Minister Göran Persson suffered a substantial political backlash for continuing to blame a range of actors, from low-level officials to the King of Sweden, after the government's mismanaged response to the 2004 Boxing Day Tsunami (Brändström et al. 2008), resulting from the Sumatra-Andaman earthquake. The alternative to blaming others is accepting responsibility. Grand gestures of this kind ('the buck stops here') are honourable, and sometimes work.

In the same tsunami case, the Norwegian government accepted responsibility for the slow and ineffective procedures that slowed down its efforts to assist the many Norwegians caught in the catastrophe. In this case, squarely absorbing the blame actually enhanced the government's political legitimacy. However, not all political cultures may be as reflexive and forgiving as the Norwegian, and many politicians will be reluctant to take the risk. Ducking, diffusing and deflecting responsibility are much more likely initial responses to crisis-induced accountability pressures than taking responsibility and absorbing the blame that comes with it (Bovens et al. 1999; Hood et al. 2009).

\section{Challenge 3: Coping with political verdicts - perseverance versus resignation}

When Official Inquiries are highly critical of a government's conduct, the apotheosis of the blame game may come to rest with leaders' decisions about their personal futures. They can try to hold out. They can deploy several tactics to defuse criticism and maintain their legitimacy: arguing that continuity is vital in a time of crisis; setting up an(other) Inquiry to 'buy time'; sacking or sanctioning lower-level officials; announcing sweeping reforms to show they have got the message.

The odds of survival are not bad. Constitutional conventions of ministerial accountability have been eroded in many countries. Criticism has to mount a higher hurdle if it is to have real consequences. Many leaders have survived devastating Inquiry reports, including Ronald Reagan in the Iran-Contra Affair, and Tony Blair over the decision to go to war in Iraq. Some leaders may feel a moral or political obligation to resign as a consequence of their role in a crisis (following the largely mythical 'Carrington doctrine') (see Woodhouse 1993). However, most crisis-induced resignations appear to stem from quite different motives, including: fundamental disagreement with the prevailing crisis response (US Secretary of State Cyrus Vance resigned in protest against the military rescue operation chosen by President Jimmy Carter to try and liberate American citizens held hostage at the US embassy in Tehran; see Farber 2004); 'lightning-rod' absorption of blame by staffers to protect the top leader (White House Chiefs of Staff or Special Advisers often perform this function in the United States; see Ellis 1994); or face-saving gestures to pre-empt a forced removal.

\section{AFTER THE FLOODS: PRESIDENT BUSH AND THE KATRINA BLAME GAME}

President Bush navigated the post-9/11 shoals in a remarkably effective way, catapulting his approval ratings and providing his administration with opportunities to implement radical policy reforms. This is the same president who is widely perceived to have failed miserably in the wake of Hurricane Katrina, which ravaged the coasts of Louisiana and Mississippi in the summer of 2005. He clung to a defensive and evasive strategy, which, 
in hindsight, proved destructive to his reputation. In the remainder of this article, we explore whether, and to what extent, President Bush's leadership style can help explain the persistent use of a failing blame-management strategy which would define the rest of his presidency.

\section{From landfall to policy fiasco}

It would be fair to say that the American public experienced the response to Hurricane Katrina as a fiasco. It is important to stress the constructed nature of fiascos (Bovens and 't Hart 1996). While the response to Hurricane Katrina saw many heroic acts and clear examples of success (Derthick 2007), it was the image of people deserted on cut-off bridges and overpasses for days, exposed to the baking sun without water or medical care, that dominated - and still does - public perception of the disaster response (Cooper and Block 2006; Dyson 2006). The pictures of increasingly desperate people in the Superdome, awaiting rescue as food and water failed to materialize, informed the image of a response failure on a massive scale. Seemingly 'out of touch' expressions of confidence in the fledgling response further framed the event for the public as one of government incompetence.

Although there were failures at all levels of government, the federal response (run by FEMA, the Department of Homeland Security, and the White House) caught most of the public blame. From a public relations perspective, this may be qualified as a self-induced disaster. President Bush lost the battle of 'meaning makers' that tends to ensue in the face of most major disasters ('t Hart 1993; Boin et al. 2009). Critics of the Bush administration used the botched response to paint a very negative picture of the Bush administration; President Bush and his advisors, in turn, failed to engage in this battle until it was too late. When they finally did, their off-key message only reinforced the emerging image of federal failure.

\section{Initial stonewalling}

Just as it had done in the wake of 9/11 (Parker and Dekker 2008; Shenon 2008), the Bush administration strongly opposed calls to establish an independent commission to investigate the federal response. The GOP-controlled Congress defeated repeated calls for an independent commission. It finally established two separate GOP-dominated congressional commissions in the House and Senate. The White House refused to fully co-operate with these Inquiries. It withheld key documents, disallowed testimony by top administration officials by invoking executive privilege, and prevented access to email traffic and other correspondence among top White House aides (such as White House Chief of Staff Andrew Card and Homeland Security adviser Frances Townsend). Henry Waxman, a Democrat Representative from California, voiced the growing frustration of many Democrats on Capitol Hill with White House co-operation when he observed, 'Our fears are turning out to be accurate... the Bush administration is stonewalling the Congress' (Lipton 2006a). Similarly, Democratic Representative Gene Taylor of Mississippi complained, 'What do they have to hide? Why don't they just come forward and say, "This is what we knew, when we knew, and this is how we reacted?"' (Lipton 2006b).

What the White House could not control, however, were inquiries by journalists, who began to dig for the underlying causes of the disaster. They focused on many issues, ranging from the role of the US Army Corps of Engineers in the construction of the failing levees, to the apparent cronyism surrounding many political appointments in FEMA and DHS. Reporters uncovered warnings that President Bush had received before the disaster 
and described in detail the tensions between the Governor of Louisiana, Ms Blanco, the Mayor of New Orleans, Mr Nagin, and President Bush.

President Bush initially held to a cautious line of defence, staying away from the disaster scene, offering material support and reassuring words ('They're doing a heck of a job'). Continued publicity, however, about FEMA director Michael Brown's qualifications undercut White House efforts to deflect blame. The White House never offered a credible storyline that could provide a counterweight to the emerging image of a non-caring administration characterized by patronage and self interest.

While political pundits used juicy details - the Arabian horse breeder who had done 'a heck of a job' - in their continuing attacks on the Bush administration, the White House did not revise its initial stance that nothing more could have been done. The strategy of stonewalling began to backfire. Negative publicity began to mount. The administration's refusal to co-operate was taken as a signal that it had something to hide. Indeed, when Time magazine published its own investigation of cronyism in the Bush Administration (Tumulty et al. 2005), it found numerous examples similar to Brown (where appointees had no relevant professional experience to qualify for their posts, beyond being Bush loyalists).

\section{Deflecting responsibility}

Before any official findings were ever presented, the White House began an attempt at political damage control. When Hurricane Rita formed and began moving towards the Gulf Coast only weeks after Hurricane Katrina, the White House sought to demonstrate that lessons had been learned from Katrina. The media was briefed in-depth about how deeply Bush was involved in calling governors and federal officials to ensure relief efforts would be carefully coordinated (Sanger 2005). The February 2006 White House Katrina report included 'lessons learned' in its title, produced 125 specific recommendations, and emphasized the President's view 'that we must do better in the future'.

There is no evidence Bush explicitly sought to use subordinates as 'lightning rods' during the Katrina case. Even when it became increasingly clear that 'Brownie' had not done 'a heck of a job' handling the crisis, Bush still defended his subordinate until a tidal wave of bipartisan criticism eventually forced Brown to be removed from oversight of the Katrina efforts, reassigned to Washington, and eventually to resign. Subordinates thus only served as 'inadvertent' lightning rods due to their official responsibilities, with first Brown taking most of the blame, followed by Secretary of Homeland Security Chertoff during later Congressional Inquiries.

During his February 2006 testimony before the Senate, Chertoff acknowledged and accepted substantial blame for the response, especially regarding his misplaced confidence in Brown (Lipton 2006a). With his mea culpa, Chertoff avoided having the committee call for his resignation, and White House press secretary Scott McClellan rewarded him by stating that 'Secretary Chertoff is doing a great job' (Lipton 2006c).

The House committee, which was composed solely of Republican members (after a boycott by Democrats) published its report, A Failure of Initiative, in February 2006. That same month, the White House issued its own Katrina report (The Federal Response to Hurricane Katrina: Lessons Learned) which accepted only limited White House blame for the outcome. Later, a non-partisan investigation by the Government Accounting Office (GAO) placed primary blame for the failed federal response on Homeland Security Secretary Chertoff rather than lower-level officials (Neuman 2006). Although these Inquiries resulted in some embarrassing revelations, the White House remained largely insulated from 
politically damaging verdicts, which settled upon lower-ranking officials (in this case, Brown and Chertoff), and a wide-range of state and local officials.

\section{Damage control}

After the Katrina Inquiries, two distinct patterns emerged. First, there was a perhaps remarkable return to the pre-disaster status quo. While President Bush publicly accepted responsibility for the slow and inadequate response, very little changed. Apart from FEMA director Michael Brown, who left early in the disaster, no other personal sacrifices were required. Chertoff scraped by, in spite of being blasted in Inquiry Reports and in the media for the delays and confusion accompanying the federal response. The Katrina Report, written by House Republicans, singled out Chertoff for blame, describing him as 'detached from events and representative of the passive reaction and misjudgements of most of Bush's top aides' (Hsu 2006). Nevertheless, calls for his resignation from members of Congress were ignored.

In addition, no major organizational or policy reforms were initiated at the federal level. While many observers noted the pre-Katrina warnings about the declining effectiveness of FEMA, as a direct result of its submergence into the Department of Homeland Security (Tierney 2005; Perrow 2007), the Bush administration did not restore FEMA's previous stature as an independent agency. Moreover, the National Response Framework, which had been severely criticized for its heavy emphasis on terrorism, was only slightly revised in the wake of Hurricane Katrina (the emphasis on terrorism remained firmly in place).

Second, the Bush administration showered federal money on the stricken Gulf region. FEMA spent almost $\$ 10$ billion on public infrastructure projects and hazard mitigation in Louisiana. The White House saw its efforts to facilitate the restoration of New Orleans hampered by a long-lasting row over the FEMA trailer parks (used to house survivors in the region). It turned out that the trailers were contaminated with potentially harmful levels of formaldehyde, further reinforcing the dominant storyline of a 'careless' and 'uncaring' government.

\section{LEADERSHIP STYLE AND BLAME MANAGEMENT: EXPLAINING THE BUSH STRATEGY}

The story of Katrina prompts two questions. First, we should ask why the Bush administration attracted much of the public blame for the seemingly inadequate response to Katrina. Even a cursory review of reports and analysis reveals numerous failures at the local and state level, as perhaps may be expected in the wake of a deadly hurricane. Yet it was President Bush who saw his remaining years in office weighed down by the public perception of failure. Mayor Nagin of New Orleans was re-elected. The first question leads to a second, more pertinent one, which asks why President Bush clung to a blame management strategy that clearly did not work. We believe his leadership style may offer an answer.

Psychological leadership research shows that political leaders display distinct and comparatively stable leadership styles, which are a function of their more deep-seated personality structures and professional socialization. Political leadership styles have been demonstrated to play an important role in shaping their government's decision-making processes, particularly during crisis episodes when the circle of decision makers tightens and leaders are expected to take the initiative (Hermann and Preston 1994; Kaarbo and Hermann 1998; Preston and 't Hart 1999; Preston 2001; Preston and Hermann 2004; Dyson and Preston 2006). 
Two dimensions of leadership style have been shown especially relevant in understanding leadership during crises: a leader's need for control and a leader's sensitivity to context (Hermann and Preston 1994; Preston and Hermann 2004). The need for personal control or involvement in the policy-making process varies across leaders, leading some to be more 'hands on' and involved, while others depend more upon subordinates and their bureaucracies. Some leaders will be more sensitive to context and seek out more information than others, which means leaders will vary greatly in terms of how quickly they 'perceive' essential elements of evolving crisis situations, how aware they are of events, and how quickly they will make decisions based on the information at hand. We briefly elaborate on both dimensions of leadership style below.

\section{Need for control/involvement}

In routine policy-making circumstances, the degree of control or personal involvement insisted upon by leaders appears to be related to their individual needs for power (Winter 1973; McClelland 1975; House 1990). Those with high power needs are typically 'hands on'. They insist on direct involvement and control over decision-making processes, actively put forward their own policy views, seek to set the agenda for their followers, centralize decision making within their inner circle of advisers, and are unlikely to delegate decision making to subordinates, hence limiting the scope for bureaucratic politics among their advisers (Preston and 't Hart 1999; Preston 2001). Leaders of this type are likely to place themselves at the heart of all key processes and decisions during a crisis. Typically, leaders with less control needs wield a hands-off approach. They focus on critical decisions, which, by definition, are important but relatively rare (Selznick 1957). They leave the implementation of these critical decisions to hand-picked subordinates, people whom they trust and rely on. This style is known as the business executive style of governance.

Leaders may benefit from a public perception of hands-on leadership style, that is, if the public perceives the crisis response to be effective and successful. Visibility, however, also makes it much harder to avoid blame if the response comes to be perceived as a failure. In contrast, less controlling leaders run the risk of either not receiving full credit for good crisis management or getting a large measure of the blame for failure (because of their perceived lack of involvement or engagement on such a critical matter). Moreover, bureau-political conflict is far more likely with this kind of style (Preston and 't Hart 1999), which can lead to public in-fighting between various officials and agencies during the aftermath. This makes it more difficult to deflect blame, since the disjointed and internally divided response is likely to be seen as a consequence of the leader's 'less engaged' management style.

\section{Sensitivity to context}

Another important dimension of leadership style is the leader's sensitivity to context and need for information before being able to make decisions. Scholars of leadership have observed substantial differences across American presidents and other world leaders in terms of their 'cognitive need' for information prior to making decisions. This need affects how prepared they are to seek out information from advisors, as well as whether they value diverse opinions or only those broadly in line with their own (George 1980; Kaarbo and Hermann 1998; Burke and Greenstein 1989; Preston 2001; Hermann et al. 2001).

US presidents scoring high in cognitive complexity (for example, with a high need for information) prefer more open advisory systems in comparison to those who score 
low (Preston 2001). Furthermore, high complexity leaders will typically be more sensitive to external policy contexts and the multiple policy perspectives that may exist on a particular issue. In the course of policy deliberations, they actively seek out information and encourage the presentation by advisors of alternative views and policy options (George 1980). They exhibit a preparedness to think about future policy contingencies, and to consider the views and reactions of other policy actors. They are not prone to deploy or accept simplistic analogies, 'black-and-white' problems or stereotyped representations of critics and opponents.

However, high complexity leaders with their emphasis upon information search and detailed policy debate, are far less decisive and require comparatively more time before being able to take crucial decisions. Such leadership traits may not always be ideal under crisis circumstances when time is at a premium. Presidents coded as low in complexity do not engage in wide-ranging information searches; they rely on inner circles and trust their policy instincts. All things being equal, they have less trouble in making snap decisions under crisis conditions.

Differences in leader sensitivity to context can have important consequences for crisis management and blame attribution. For example, under normal decision-making circumstances, high complexity leaders who require time for information gathering and deliberation are likely to produce more considered, high quality decisions. During and after a crisis, however, they are politically vulnerable to blame from a public and media who expect swift, decisive interventions. In addition, particularly in the case of disasters and catastrophes, high societal costs such as death, injury, disease and critical infrastructure breakdowns provide political opponents with the ammunition to attack 'ineffective' leadership.

In contrast, we would expect low complexity leaders to react (in some form or another) much quicker to a crisis than their high complexity counterparts and to more rapidly develop a 'frame' of the scale and significance of the crisis (as well as the type of response that is needed), in a manner consistent with their pre-existing personal/political beliefs. This can be construed as the pinnacle of crisis leadership - the true decider - but it may also be perceived, with or without the benefit of hindsight, as 'shooting from the hip' or even as reckless carelessness. These leaders walk a fine line between heroism and scorn.

Table 1 outlines how the characteristics of leaders leave them more or less vulnerable to pressures of accountability and blaming. We surmise that leaders' operating styles and advisory arrangements leave them vulnerable to certain kinds of malfunctions or problems that may later come 'home to roost' during the blame games after a crisis. It is important to note that there are no prima facie empirical reasons to presuppose that particular blame management strategies themselves are limited to any given leadership style type. After all, when confronted with crisis or scandal, presidents with very different leadership styles such as Nixon (on Watergate), Clinton (on Lewinsky) and Bush (on Iraq and Katrina) all set out initially to stonewall and obstruct, refusing to co-operate with Inquiries.

We may infer from table 1, however, that different types of leaders have different degrees of susceptibility to particular kinds of blame attribution in the wake of crises. This is because their preferred leadership styles have different strengths and weaknesses associated with them and these are often widely known and debated prior to the occurrence of a crises and are an obvious focal point for media and expert commentary. Different types of leaders are also likely to face different kinds of blame management challenges in the wake of a crisis. For example, leaders emphasizing loyalty over expertise 


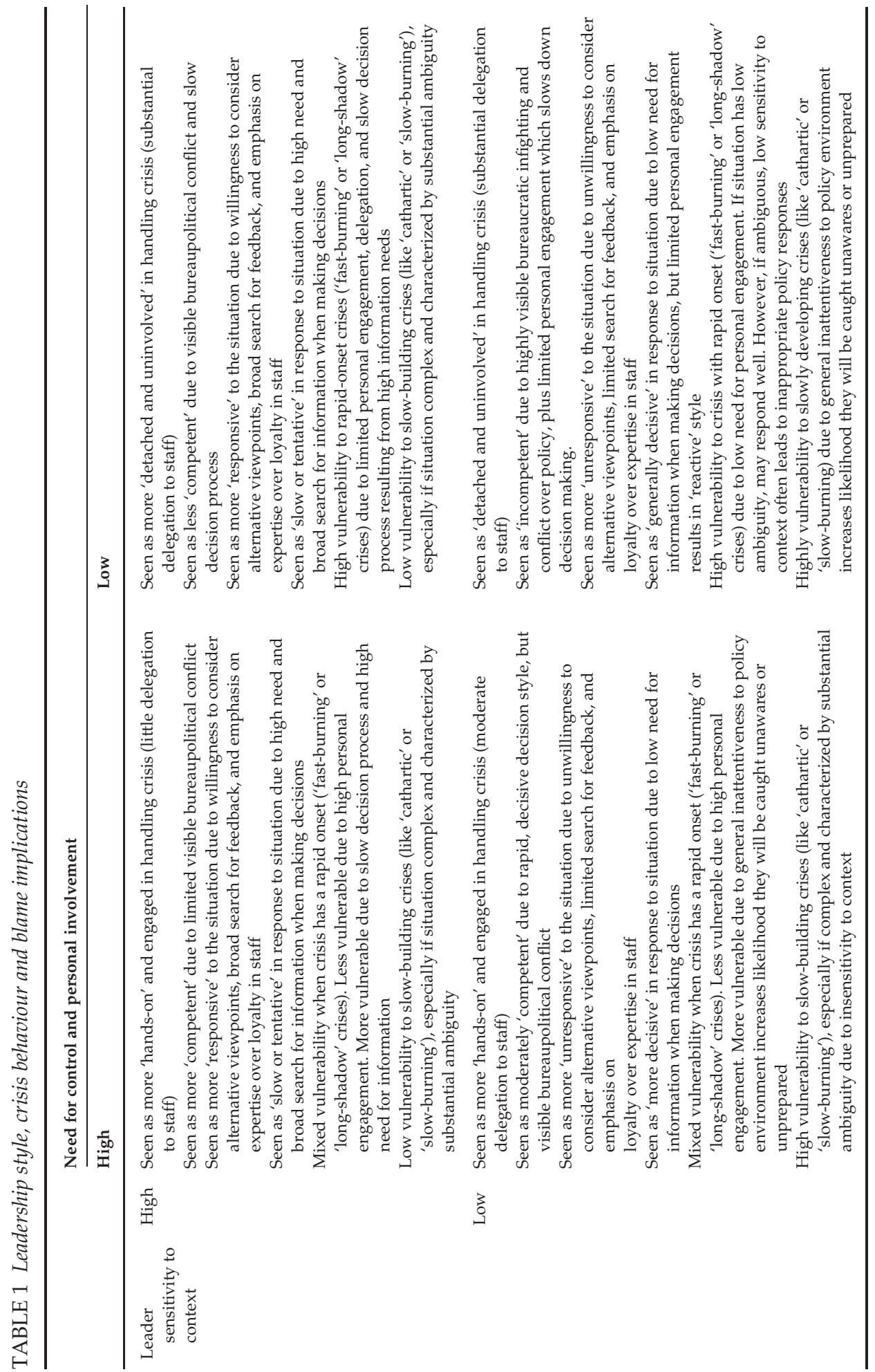


are more likely to face criticism with regard to their use of purely political operators and allies in posts that require considerable administrative skills. That is the type of blame game 'problem' that a leader emphasizing expertise over loyalty likely would not face.

Likewise, leaders widely seen as having a controlling style may find it impossible to successfully deny personal knowledge and responsibility for controversial acts, as President Reagan did in the wake of the Iran-Contra scandal. Paradoxically, Reagan's often ridiculed reputation for having an extremely 'hands-off' style quite possibly saved him from the scathing findings of the Tower Commission, since it made his key defence line - I did not know what exactly was being done in my name - sound rather plausible. And so Oliver North and John Poindexter took the fall, and Reagan's popularity quickly rebounded after the crisis subsided (Schudson 1990).

In sum, this framework suggests that leadership styles leave them more, or less, vulnerable to blame attribution during post-crisis scrutiny. But we do not know how particular patterns of blame attribution and blame management are associated with leaders with specific placements in the 2x2 leadership style space. This requires detailed empirical analysis of leadership styles and blame attribution. In the section that follows, we conduct a preliminary plausibility probe of this framework.

The sources of data for this case must, of necessity, rely upon journalistic accounts and congressional testimonies of participants. Obviously, there is the potential for bias in such data and it is undoubtedly not a complete record of the decision processes within the Bush administration surrounding Katrina. However, these still represent (in the absence of official records which become available after 30 years and publication of participant memoirs) the best available data on the case at present and every effort has been made to find multiple corroboration of accounts described in this case study.

\section{The leadership style of President George W. Bush}

President George W. Bush employed a very distinct leadership style. In a population of over 250 world leaders scored on Margaret Hermann's (1980a, b, 1983, 1984, 2003) Leader Trait Assessment scale, President Bush ranked relatively low on 'need for power' and 'general sensitivity to context' (Preston and Hermann 2004). President Bush believes 'one must act from convictions' and has publicly stated that 'I am not going to negotiate with myself' (Hargrove 2007, p. 229). As a Harvard Business School graduate, he combined a business executive style with a strong executive team. After listening to the arguments, the President decided. Public opinion simply did not enter into the equation (Hargrove 2007), as Bush himself emphatically re-iterated in early auto-retrospectives on his presidency during his final months in office.

President Bush's leadership style thus approximates an ideal type in table 1. His actions during and after Katrina are fully in line with this ideal type, which would suggest hands-off crisis management, a pro forma acceptance of responsibility, strong loyalty to subordinates, and a post-event conviction that the way it was handled did not require second guessing. This is neither an inherently bad (or good) way of managing a crisis. But this style does not work well for leaders who find themselves in a vulnerable position. It makes them look detached from reality, secretive and rigid. The lack of symbolic gestures of contrition (derided by Bush as 'pandering to public opinion') leaves a president with this leadership style wide open for attack.

In the summer of 2005, the Bush administration suffered from a general perception of declining presidential performance. By the time Katrina hit - and as opposed to the time of the 9/11 crisis - Bush had faced multiple 'accountability episodes' that had begun 
to sap his credibility with the public. These included the increasingly unpopular war in Iraq; the failure to find weapons of mass destruction in Iraq; allegations of misuse of intelligence to justify the war; and investigations of senior White House aides Scooter Libby and Karl Rove. This series of political controversies was accompanied by a steady decline in approval ratings (Bowman 2008). As a result, the Administration's response to Katrina would not be judged in isolation, but within the context of an overall negative political climate. This greatly complicated the Administration's efforts to formulate and 'sell' a winning frame.

The advisory arrangements and style of decision making within the Bush Administration exacerbated its vulnerable position. Substantial aspects of policy-making and implementation were entrusted to loyal subordinates. Direct presidential oversight was the exception rather than the rule (Kahn 2000; Milbank 2000; Berke 2001; McClellan 2008). One consequence was high levels of inter- and intra-agency and departmental conflict (Duffy 2002; Sanger 2002). Particularly noteworthy were the struggles between the Pentagon, CIA, National Security Council and State Department over Iraq policy (Sipress 2002; Zakaria 2002; Moens 2004; Suskind 2004; Mitchell 2005, pp. 174-98; Ricks 2006; Gordon and Trainor 2006; Suskind 2007).

President Bush's inner circle of advisers and his political appointees were predominantly comprised of 'like-minded' individuals whose personal loyalty was often considered more important than professional qualifications or expertise (Preston 2001; Mann 2004; Moens 2004; Tumulty et al. 2005; McClellan 2008). For leaders such as Bush, the emphasis on loyalty over expertise works both ways. In the face of intense media and public scrutiny, they are less inclined to breach their own principles and sacrifice loyal advisors for the sake of political expediency.

The closed nature of Bush's advisory system created hurdles for dissonant views. The consequence was a reduction in the ability to actively or accurately monitor the policy and political environments for feedback or relevant information (Allen 2005). Negative feedback or warnings coming from sources outside the Administration were less likely to be heard. President Bush's leadership style facilitated policies that were driven more by idiosyncratic factors or ideological beliefs than a monitoring of the existing political context. It also increased vulnerability to blame in the face of adversity.

This pre-existing political context would prove critical. President Bush did not enter the post-disaster phase with a clean slate politically speaking. Instead of a situation where blame can be relatively easily deflected, his slate made him a political magnet attracting blame. The pre-existing political context meant the Bush Administration could ill afford to appear unprepared, ineffectual, or purposefully misleading over Katrina. Yet, President Bush's leadership style did exactly that. It significantly influenced the character of the Administration's crisis management response, which, in turn, made it even more vulnerable to the blame game that followed immediately in Katrina's aftermath.

President Bush's leadership style during the first days after Katrina made landfall reinforced the perception of a leader out of touch with reality. The optimistic reactions by Bush and White House spokesmen about the federal response and the situation on the ground in New Orleans were soon refuted by media coverage of the situation and rescue workers on the scene (Stevenson 2005; Thomas 2005). The President's refusal to visit New Orleans - he preferred to fly over the stricken area - and his willingness to visit Senator Trent Lott in Mississippi were widely considered as insensitive. Detractors portrayed the President as being either out-of-touch with events (at best) or downright duplicitous (at worst) - neither of which judgement helped the Administration deflect blame. 
Past decisions now came to haunt Bush's administration since they were suddenly reinterpreted in a new and rather unforgiving light. The deployment of Louisiana's National Guard to Iraq meant the state was short-handed in its response to the storm and this helped critics to link the response failure to the increasingly unpopular war in Iraq. The Bush Administration had substantially cut the Army Corps of Engineers budgets for levee repairs and improvements around New Orleans in the years preceding Katrina (despite repeated warnings about the threat posed by major storms) by more than half, which created a direct causal relation between Bush and Katrina (Blumenthal 2005; Ripley 2005).

Bush's style of substantial delegation to subordinates, limited active involvement, and emphasis upon loyalty over expertise in appointments, served to pre-set the roles of many of the policy actors prior to Katrina - actors (such as FEMA director Brown and Homeland Security Secretary Chertoff) whose performances would later be criticized. Subsequent media investigations into the backgrounds of Bush political appointees opened up the Administration to accusations of cronyism and placing officials (such as Brown) into posts for which they were not qualified (Tumulty et al. 2005). Such charges were especially damaging, given the importance (and failure) of federal emergency managers in the response to a disaster of this magnitude.

The unremitting public pressure led Bush to quickly acknowledge, during a press conference on 13 September, that 'to the extent that the federal government didn't fully do its job right, I take responsibility' (Bumiller and Stevenson 2005). While Bush accepted responsibility, a counterattack from the White House questioned the political motives of opponents. Press Secretary McClelland used the term 'blame game' 15 times over the course of just two White House press briefings when confronted with criticism of the Administration's response (Krugman 2005).

Rather than moving on quickly, President Bush prioritized the reconstruction of New Orleans and the wider Gulf area on his policy agenda. This may be interpreted as a cynical effort to correct some of the mistakes his administration had made. It is, however, also fully consistent with President Bush's leadership style, which is to pursue 'what should be done' as a matter of principle. While the president refused to reform DHS and FEMA (the responsible agents for failure according to many), he consistently supported money flowing down south, long after other priorities had begun to dominate the national attention cycle. Post-Katrina, FEMA alone has spent almost $\$ 7$ billion, comprising $\$ 1.47$ billion for hazard mitigation and $\$ 6.1$ billion in individual assistance.

\section{CONCLUSION: RECONSIDERING THE ROLE OF CRISIS LEADERSHIP STYLE}

Studying how leaders, governments and oppositions deal with the politics of crisisinduced Inquiry, accountability and blame is essential for anyone seeking to understand the political impacts of crises. We have argued that in coping with the politics of post-crisis management, leaders need to forge pathways through: (1) Public Inquiries (stonewalling versus cooperating); (2) public criticism (denying versus acknowledging responsibility); and (3) political verdicts (persevere versus resign). Furthermore, we have refined this framework by demonstrating that a leader's pattern of behaviour with regard to these challenges derives from his or her more general leadership style (and the types of vulnerabilities this is likely to generate in the operational crisis response phase).

We applied this framework to George W. Bush and Hurricane Katrina, finding that Bush's leadership style made him and his Administration vulnerable to charges of 
negligence and mismanagement. In the wake of Katrina, President Bush's leadership style reinforced the general perception of his performance, which, in the end, left him with much of the blame. His leadership profile would predict him to assume a hands-off crisis management approach, to leave operations to ground staff, to back his staff to the hilt, to assume full responsibility without accepting the political consequences - exactly as it happened throughout the aftermath of Hurricane Katrina.

It appears that substantial delegation to subordinates, coupled with limited attention to the surrounding policy environment, informed the President's personal response to the crisis. Not only was Bush's leadership style ill-fitted to the nature of the crisis in which he found himself, his past decisions (for example, appointment of loyalists rather than experts to critical emergency management positions) caught up with him during and in the wake of Katrina. His proclivity to 'stay the course' did not help either: it led to a pattern of political crisis management that exacerbated rather than belied the public perception's of leadership failure.

We cannot, of course, generalize from one case. But we can offer some pointers for those seeking to understand the aftermath of crisis. Future studies of leadership and blame games should further develop the distinction developed here between susceptibility to blame attribution and likelihood to employ particular sets of blame management strategies. An important avenue of research would be to explore various leadership style types across various types of crises to further examine the hypothesized relationships between style, political management strategy, and the political and policy impacts of crises. Are certain 'types' of leaders more likely to adopt specific kinds of management strategies? How do these interact with different forms of post-crisis investigation in shaping the political fates of leaders and governments? Can we identify more and less politically efficacious blame management strategies?

Future research should also examine the relation between the process and outcomes of blame games. While President Bush lost the public meaning-making contest, he could claim victory in the political battle. He escaped explicit blame verdicts in the various Public Inquiries. This outcome fits neatly with the leadership style described in this article: stay the course and all will work out. Future research in a variety of cases will have to show whether President Bush is a master strategist or just got lucky.

\section{ACKNOWLEDGEMENT}

A much earlier version of this paper entitled 'Inertia or Change? Crisis-induced Challenges for Political Leaders', was presented to the Australasian Political Studies Association Conference, University of Newcastle, Australia, 25-27 September 2006. We wish to thank participants for their helpful comments and suggestions.

\section{REFERENCES}

Allen, M. 2005. 'Living Too Much in the Bubble?: A Bungled Initial Response to Katrina Exposed the Perils of a Rigid, Insular White House', Time, 19 September.

Berke, R.L. 2001. 'Jokes Remain, But Many Say Bush is Showing Signs of War's Burden', New York Times, 9 December.

Blumenthal, S. 2005. 'Katrina Comes Home to Roost', The Guardian, 4 September.

Boin, A. and P. 't Hart. 2003. 'Public Leadership in Times of Crisis: Mission Impossible?', Public Administration Review, 63, 5, 544-53.

Boin, A., P. ‘t Hart, E. Stern and B. Sundelius. 2005. The Politics of Crisis Management: Public Leadership under Pressure. Cambridge: Cambridge University Press.

Boin, A., A. McConnell and P. 't Hart (eds). 2008. Governing After Crisis: The Politics of Investigation, Accountability and Learning. Cambridge: Cambridge University Press. 
Boin, A., P. 't Hart and A. McConnell. 2009. ‘Towards a Theory of Crisis Exploitation: Political and Policy Impacts of Framing Contests and Blame Games', Journal of European Public Policy, 16, 1, 81-106.

Bovens, M. 1998. The Quest for Responsibility: Accountability and Citizenship in Complex Organizations. Cambridge: Cambridge University Press.

Bovens, M. and P. ‘t Hart. 1996. Understanding Policy Fiascoes. New Brunswick, NJ: Transaction Press.

Bovens, M., P. 't Hart., S. Dekker and G. Verheuvel. 1999.'The Politics of Blame Avoidance: Defensive Tactics in a Dutch Crime-fighting Fiasco', in H.K. Anheier (ed.), When Things Go Wrong: Organizational Failures and Breakdowns. London: Sage, pp. $123-47$.

Bowman, K. 2008. Public Opinion on the War with Iraq. American Enterprise Institute for Public Policy Research (http:/ / www.aei. org/publications/pubID.22142/pub_detail.asp), accessed 28 July 2008.

Brändström, A. and S. Kuipers. 2003. 'From “Normal Incidents” to Political Crises: Understanding the Selective Politicization of Policy Failures', Government and Opposition, 38, 3, 279-305.

Brändström, A., S. Kuipers and P. Daléus. 2008. 'The Politics of Tsunami Responses: Comparing Patterns of Blame Management in Scandinavia', in A. Boin, A. McConnell and P. 't Hart (eds), Governing After Crisis: The Politics of Investigation, Accountability and Learning. Cambridge: Cambridge University Press, pp. 114-47.

Bumiller, E. and R.W. Stevenson. 2005. 'President Says He's Responsible in Storm Lapses', New York Times, 14 September.

Burke, J.P. and F.I. Greenstein. 1989. How Presidents Test Reality: Decisions on Vietnam, 1954 and 1965. New York: Russell Sage Foundation.

Cooper, C. and R. Block. 2006. Disaster: Hurricane Katrina and the Failure of Homeland Security. New York: Times Books.

Derthick, M. 2007. 'Where Federalism Didn't Fail', Public Administration Review, 67, 1, 36-47 (special issue).

Drennan, L.T. and A. McConnell. 2007. Risk and Crisis Management in the Public Sector.London: Routledge.

Duffy, M. 2002. 'Trapped By His Own Instincts', Time, 6 May.

Dyson, M.E. 2006. Come Hell or High Water: Hurricane Katrina and the Color of Disaster. New York: Basic Books.

Dyson, S.B. and T. Preston. 2006. 'Individual Characteristics of Leaders and the Use of Analogy in Foreign Policy Decision Making', Political Psychology, 27, 2, 265-88.

Elliot, D. and M. McGuiness. 2002. 'Public Inquiry: Panacea or Placebo?', Journal of Contingencies and Crisis Management, 10, 1, $14-25$.

Ellis, R.J. 1994. Presidential Lightning Rods: The Politics of Blame Avoidance. Lawrence, KS: University of Kansas Press.

Farber, D. 2004. Taken Hostage: The Iran Hostage Crisis and America's First Encounter with Radical Islam. Princeton, NJ: Princeton University Press.

Flin, R. 1996. Sitting in the Hot Seat: Leaders and Teams for Critical Incident Management. New York: John Wiley.

Flinders, M.V. and M.J. Smith (eds). 1999. Quangos, Accountability and Reform. Basingstoke: Macmillan.

George, A.L. 1980. Presidential Decisionmaking in Foreign Policy. Boulder, CO: Westview Press.

Gordon, M.R. and B.E. Trainor. 2006. Cobra II: The Inside Story of the Invasion and Occupation of Iraq. New York: Pantheon.

Hargrove, E.C. 2007. The Effective Presidency: Lessons on Leadership from John F. Kennedy to George W. Bush. Boulder, CO: Paradigm.

Hart, P. 't. 1993. 'Symbols, Rituals and Power: The Lost Dimensions of Crisis Management', Journal of Contingencies and Crisis Management, 1, 1, 36-50.

Hearit, K.M. 2006. Crisis Management by Apology. Malawah, NJ: Lawrence Erlbaum.

Hermann, M.G. 1980a. 'Explaining Foreign Policy Behavior Using Personal Characteristics of Political Leaders', International Studies Quarterly, 24, 1, 7-46.

Hermann, M.G. 1980b. 'Comments on Foreign Policy Makers Personality Attributes and Interviews: A Note on Reliability Procedures', International Studies Quarterly, 24, 1, 67-73.

Hermann, M.G. 1983. Handbook for Assessing Personal Characteristics and Foreign Policy Orientations of Political Leaders. Columbus, OH: Mershon Center Occasional Papers.

Hermann, M.G. 1984. 'Personality and Foreign Policy Decision Making: A Study of 53 Heads of Government', in D.A. Sylvan and S. Chan (eds), Foreign Policy Decision Making: Perceptions, Cognition, and Artificial Intelligence. New York: Praeger, pp. 53-80.

Hermann, M.G. 2003. 'Assessing Leadership Style:Trait Analysis', in J.M. Post (ed.), The Psychological Assessment of Political Leaders. Ann Arbor, MI: The University of Michigan Press, pp. 178-212.

Hermann, M.G. and T. Preston. 1994. 'Presidents, Advisers, and Foreign Policy: The Effect of Leadership Style on Executive Arrangements', Political Psychology, 15, 1, 75-96.

Hermann, M.G., T. Preston, B. Korany and T.M. Shaw. 2001. 'Who Leads Matters: The Effects of Powerful Individuals', in J. Hagan and M.G. Herman (eds), Leaders, Groups, and Coalitions: Understanding the People and Processes in Foreign Policymaking. Boston, MA: Blackwell, pp. 83-131.

Hood, C.C. 2002. 'The Risk Game and the Blame Game', Government and Opposition, 37, 1, 15-37.

Hood, C.C., W. Jennings, B. Hogwood and C. Beeston. 2009. 'Fighting Fires in Testing Times: Exploring a Staged Response Hypothesis for Blame Management in Two Exam Fiasco Cases', European Journal of Political Research, 48, 6, 695-722. 
House, R.J. 1990. 'Power and Personality in Complex Organizations', in B.M. Staw and L.L Cummings (eds), Personality and Organizational Influence. Greenwich, CT: JAI Press, pp. 181-233.

Hsu, S.S. 2006. 'Katrina Report Spreads Blame: Homeland Security, Chertoff Singled Out', The Washington Post, 12 February 2006.

Kaarbo, J. and M.G. Hermann. 1998. ‘Leadership Styles of Prime Ministers: How Individual Differences Affect the Foreign Policy Process', Leadership Quarterly, 9, 3, 243-63.

Kahn, J. 2000. 'Bush Filling Cabinet With Team of Power-Seasoned Executives', New York Times, 31 December.

Kitts, K. 2006. Presidential Commissions and National Security. Boulder, CO: Lynne Rienner.

Krugman, P. 2005. 'Point Those Fingers', International Herald Tribune, 9 September.

Lipton, E. 2006a. 'White House Declines to Provide Storm Papers', New York Times, 25 January.

Lipton, E. 2006b. 'A Mountain of Documents on Hurricane Response, but Democrats Seek More', New York Times, 26 January.

Lipton, E. 2006c. 'Senators Assail Chertoff's Job Handling Storm: Lawmakers From Both Parties Cite Failures', New York Times, 16 February.

McClellan, S. 2008. What Happened: Inside the Bush White House and Washington's Culture of Deception. New York: Public Affairs.

McClelland, D.C. 1975. Power: The Inner Experience. New York: Irvington.

McGraw, K. 1990. 'Avoiding Blame: An Experimental Investigation of Political Excuses and Justifications', British Journal of Political Science, 20, 2, 119-32.

McGraw, K. 1991. 'Managing Blame: An Experimental Test of the Effects of Political Accounts', American Political Science Review, $85,4,1133-57$.

Mann, J.E. 2004. Rise of the Vulcans: The History of Bush's War Cabinet. London: Viking.

Milbank, D. 2000. 'The Chairman and the CEO: In Incoming Corporate White House, Bush is Seen Running Board, Cheney Effecting Policy', Washington Post, 24 December.

Mitchell, D. 2005. Making Foreign Policy: Presidential Management of the Decision-Making Process. Aldershot: Ashgate.

Moens, A. 2004. The Foreign Policy of George W. Bush: Values, Strategy and Loyalty. Aldershot: Ashgate.

Neuman, J. 2006. 'GAO Puts Blame on Chertoff for Katrina Fiasco', Baltimore Sun, 2 February.

Olson, R.S. 1998. 'Towards a Politics of Disaster: Losses, Values, Agendas and Blame', International Journal of Mass Emergencies and Disasters, 18, 2, 265-87.

Parker, C.F. and S. Dekker. 2008. 'September 11 and Post-crisis Investigation:

Exploring the Role and Impact of the 9/11 Commission', in A. Boin, A. McConnell and P. 't Hart (eds), Governing After Crisis: The Politics of Investigation, Accountability and Learning. Cambridge: Cambridge University Press, pp. 255-82.

Perrow, C. 2007. The Next Catastrophe: Reducing our Vulnerabilities to Natural, Industrial, and Terrorist Disasters. Princeton, NJ: Princeton University Press.

Prasser, S. 2006. Royal Commissions and Public Inquiries in Australia. Chatswood, NSW: LexisNexis/Butterworths.

Preston, T. 2001. The President and His Inner Circle: Leadership Style and the Advisory Process in Foreign Affairs. New York: Columbia University Press.

Preston, T. and P. 't Hart. 1999. 'Understanding and Evaluating Bureaucratic Politics: The Nexus Between Political Leaders and Advisory Systems', Political Psychology, 20, 1, 49-98.

Preston, T. and M.G. Hermann. 2004. 'Presidential Leadership Style and the Foreign Policy Advisory Process', in E.R. Wittkopfand and J.M. McCormick (eds), The Domestic Sources of American Foreign Policy: Insights and Evidence, 4th edn. New York: Roman \& Littlefield, pp. 363-80.

Resodihardjo, S.L. 2006. Crisis and Change. Understanding Crisis-Reform Processes in Dutch and British Prison Services. Amsterdam: Amsterdam University Press.

Ricks, T.E. 2006. Fiasco: The American Military Adventure in Iraq. New York: Penguin.

Ripley, A. 2005. 'An American Tragedy: How Did This Happen?', Time, 12 September.

Rosenthal, U. 1998. 'Future Disasters, Future Definitions', in E.L. Quarantelli (ed.), What is a Disaster: Perspectives on the Question. London: Routledge, pp. 146-60.

Rosenthal, U., M.T. Charles and P. 't Hart (eds). 1989. Coping with Crisis: The Management of Disasters, Riots and Terrorism. Springfield, IL: Charles C. Thomas.

Sanger, D.E. 2002. 'War Was Easy. The Rest of the World is a Mess', New York Times, 21 April.

Sanger, D.E. 2005. 'Bush Compares Responses to Hurricane and Terrorism', New York Times, 22 September.

Schudson, M. 1990. 'Ronald Reagan Misremembered', in D. Middleton and D. Edwards (eds), Collective Remembering. London: Sage, pp. 108-19.

Selznick, P. 1957. Leadership in Administration: A Sociological Interpretation. New York: Row-Peterson.

Shenon, P. 2008. The Commission: The Uncensored History of the 9/11 Commission. New York: Twelve.

Sipress, A. 2002. 'Policy Divide Thwarts Powell in Mideast Effort: Defense Department's Influence Frustrates State Department', Washington Post, 26 April.

Stevenson, R.W. 2005. 'In First Response to Crisis, Bush Strikes Off-key Notes', New York Times, 3 September. 
Suskind, R. 2004. The Price of Loyalty: George W. Bush, the White House, and the Education of Paul O'Neill. New York: Simon \& Schuster.

Suskind, R. 2007. The One Percent Doctrine: Deep Inside America's Pursuit of Its Enemies Since 9/11. New York: Simon \& Schuster. Thomas, E. 2005. 'How Bush Blew it', Newsweek, 19 September.

Thompson, D.F. 1980. 'Moral Responsibility of Public Officials: The Problem of Many Hands', American Political Science Review, $74,4,905-16$.

Tierney, K.J. 2005. 'Recent Developments in U.S. Homeland Security Policies and Their Implications for the Management of Extreme Events', Paper Presented at the First International Conference on Urban Disaster Reduction, Kobe, Japan, 18-20 January (http:/ / training.fema.gov/emiweb/downloads/Tierney2005japanfinal2.pdf), accessed 29 July 2008.

Toft, B. and S. Reynolds. 2005. Learning from Disasters: A Management Approach, 3rd edn. Leicester: Perpetuity Press.

Tumulty, K., M. Thompson and M. Allen. 2005. 'How Many More Mike Browns Are Out There?', Time, 3 October, pp. 49-54.

Ulmer, R.R., T.L. Sellnow and M.W. Seeger. 2007. Effective Crisis Communication: Moving From Crisis to Opportunity. Thousand Oaks, CA: Sage.

Weaver, R.K. 1986. 'The Politics of Blame Avoidance', Journal of Public Policy, 6, 4, 371-98.

Winter, D.G. 1973. The Power Motive. New York: The Free Press.

Woodhouse, D. 1993. 'Ministerial Responsibility in the 1990s: When Do Ministers Resign?', Parliamentary Affairs, 46, 3, $277-92$.

Zakaria, F. 2002. 'Colin Powell's Humiliation: Bush Should Clearly Support His Secretary of State - Otherwise He Should Get a New One', Newsweek, 29 April.

Date received 29 January 2008. Date accepted 22 October 2008. 